\title{
Profit Persistence Revisited: The Case of the UK
}

\author{
David G. McMillan \\ School of Management \\ University of St. Andrews \\ Fife KY16 9SS \\ Scotland, UK \\ Phone: 011-44-1334-46-2201 \\ Fax: 011-44-1334-46-2444 \\ E-mail: dgm6@st-andrews.ac.uk \\ Mark E. Wohar* \\ Department of Economics \\ RH-512K \\ University of Nebraska at Omaha \\ Omaha, NE 68182-0286 \\ Phone: 402-554-3712 \\ Fax: 402-554-2853 \\ E-mail: mwohar@mail.unomaha.edu
}

*Corresponding author.

$J E L$ classifications: $* * *$

Key words: ***

Acknowledgements: We thank $* * *$ for their very helpful comments on earlier drafts. The usual disclaimer applies. 


\title{
Profit Persistence Revisited: The Case of the UK
}

\begin{abstract}
This paper uses data on 57 firms over the period 1980-2007 to investigate profit persistence. We add to this literature by considering an asymmetric autoregressive model which allows the parameter governing persistence to vary between positive and negative profits relative to normal profits. Thus, we are able to differentiate between entry and exit as conduits of the competitive model. Should the persistence parameters be asymmetric, then this sheds light on whether the threat of entry or exit is more dominant in asserting the competitive equilibrium. Such information may be of importance to policy makers in establishing competition legislation. We find firms with profits above normal are firms that have high barriers to entry and exit while firms with below normal profits have low barriers to entry and exit.
\end{abstract}




\section{Introduction}

The degree of persistence in firm profits remains an open question in the empirical literature. From a theoretical standpoint the competitive process should eliminate abnormal profits. That is, where a firm is making excess profits then competitor firms should enter the market offering the same product at a lower price until profits return to the competitive rate. Similarly, firms whose profits are below the average rate will either be eliminated as investors move to markets with a higher profits rate or the firms will take measures to return to average market profit. However, in research dating back to Mueller $(1977,1986)$ and extended by Geroski and Jacquemin (1988) and Geroski (1990) the effectiveness of this competitive model has been questioned. In particular, this line of research established that profit persistence measures can be estimated using an autoregressive model of order one, and showed that persistence measures were not always consistent with the competitive equilibrium model.

This early work led to, what has become known as the persistence of profits literature. In this developing literature, for which examples include, Cubbin and Geroski (1990), Schohl (1990), Droucopoulos and Lianos (1993), Kambhampati (1995), Goddard and Wilson (1996, 1999), McGahan and Porter (1999) and Glen et al (2001), measures of profit persistence are often large and inconsistent with competitive equilibrium. Even allowing for abnormal profits due to entry and exit barriers and the advantages that accrue with first-mover advantage, profit

persistence is too high, for example, Mueller (1990) concluded that profits persist in a range of West European and North American economics, while, Maruyama and Odagiri (2002) likewise conclude that profit persistence is too high in a selection of Japanese firms. Similarly, Gschwandtner (2005) reports that profits persist for a period of over fifty years in US firm data.

As noted, the methodology typically applied in measuring the persistence of profits is 
based around a first-order autoregressive model, with few departures from this approach. A few exceptions to this include Gschwandtner and Hauer (2007) who consider a fractional integration approach and report evidence of both long-range dependency and non-stationarity. While Crespo Cuaresma and Gschwandtner (2006) consider a non-linear three-regime threshold model, with a middle random walk regime and symmetric reverting outer behaviour and report lower levels of persistence than typically in linear studies.

This paper seeks to contribute to the existing literature in two ways. First, we update the results to include a more recent time period than the existing research. Our data set extends until 2007, whereas much of the existing literature uses data that does not include the 2000's. This may be of importance given the significant stock market turbulence over the period, as well as the preceding bubble, which has led to substantial turnover of firms, entering and exiting. The second, and perhaps more significant, aim of the paper is to consider an asymmetric autoregressive model. While the work of Crespo Cuaresma and Gschwandtner (2006) considered non-linear estimation, they retained symmetry of the persistence parameter. This paper allows the parameter governing persistence to vary between positive and negative profits relative to the norm. Thus, we are able to differentiate between entry and exit as conduits of the competitive model. That is, while the above work assumes that the persistence of profits is equal regardless of whether any particular firm is faced with possible exit or the threat of competitor firms entering, our modelling approach allows direct testing of this. Moreover, should the persistence parameters be asymmetric, then this sheds light on whether the threat of entry or exit is more dominant in asserting the competitive equilibrium. Such information may be of importance to policy makers in establishing competition legislation.

The rest of the paper follows with Section 2 that reviews the key literature, Section 3 that 
presents the empirical methodology, Section 4 that introduces the data and empirical results and Section 5 that summarises the findings and presents the key implications of the results.

\section{Literature Review}

Beginning with the work of Mueller $(1977,1986)$ there has been a growing literature that attempts to deal with the empirical puzzle of the competitive environment hypothesis. Although the competitive process should eliminate profit differentials between different firms/industries, in the long-run, this is not what is observed in the empirical literature. The theory states that if a firm has excess profits the competitors will enter the market offering similar products at lower costs until the profitability in the market equals the competitive profit rate. If firms have profits that are below average, firms will move to markets with higher profits and firms with below average profits will go out of business unless corrective measures are introduced, restoring at least normal profits. However, this theory does not have empirical support in the literature and profits seem to persist.

Some of the papers that have found evidence for profit persistence for different countires and different time periods include Odagiri and Yamawaki (1986, 1990a,b), and Odagiri and Hayawaki (1990) and Maruyama and Odagiri (2002) for Japan, Cubbin and Geroski $(1987,1990)$ and Goddard and Wilson (1999), Gschwandter (2005) and Gschwandter and Hauser (2007) for the UK, Geroski and Jacquemin (1988) for the UK, France and Germany, Schwalbach, Grasshof, and Mahmood (1989) for Germany, Khemani and Shapiro (1990) for Canada, for Japan, Schohl (1990) for Germany, Mueller (1990a) for many countries, Mueller (1990b) and Waring (1996) for the US, Schwalbach and Mahmood (1990) for Germany, Kambhampati (1995) for India, McGahan and Porter (1999), Cable et al. (2001), Glen et al. (2001) for nine developing 
countries, Ioannidis, Peel, and Venetis (2003), Yurtoglu (2004) for Turkey. ${ }^{1}$

Yurtoglu (2004), examining Turkey, tries to answer three questions that are central to industry dynamics; i) do competitive forces successfully eliminate excess profits? ii) how quickly does the erosion process take place? And iii) which factors account for the observed differences in profit persistence and for the speed of adjustment to the norm? His analysis of firm persistence of firm level profitability in Turkey reveals that the intensity of competition in Turkey is no less than that in developed countries. Glen et al. (2001) analyses the persistence of profitability and competition in seven emerging markets and concludes that the intensity is greater in emerging markets than in developed economies.

The existence of a unit root in firm-level profitability series should indicate that shocks to profitability persist indefinitely and that competitive pressures never erode differences in profitability. One unit root test used often is the Augmented Dickey-Fuller (ADF) test which tests for stationarity. A common problem with these tests is that they have low power against a stationary alternative (Crespo-Cuareshma and Geschwandtner 2006). Yurtoglu (2004) have Dickey-Fuller (DF) tests that fail to reject the null in only 56 out of 172 cases. $^{2}$ Kambhampati (1995) and Goddard and Wilson (1999) investigate stationarity of profits. Kambhampati (1995) and Goddard and Wilson (1999) find that the coefficients on lags in an autoregressive model greater than one were in the majority of cases insignificantly different from zero. Geroski and Jacquemin (1988), found that slightly more than 82 percent of UK firms (and 95 and 79 percent of French and West German Firms), had coefficients greater than one autoregressive lag equal to zero. Similarly, Yurtoglu (2000) reports similar results for 92 percent of Turkish firms. ${ }^{1}$ Mueller (1990a) analyses profit persistence in seven developed countries (Canada, France, Japan, Sweden, UK, US, and West Germany). He concludes that profit persistence exists in all of these countries.

${ }^{2}$ This number is based on a DF equation with a constant and no lags. 
Therefore, eliminating the lagged variables beyond one year and apply the AR(1) equation to all firms should not change the pattern of results.

The above studies use an AR(1) process as a representation of the dynamics of profits. A few studies have extended this methodology. Cable et al. (2001) proposes a structural time series analysis to describe profit dynamics. Crespo-Cuareshma and Geschwandtner (2006) use a nonlinear approach. Crespo-Cuareshma and Geschwandtner (2005) consider time-varying persistence of profits.

The study by Gschwandter (2005) notes that one limitation of previous studies is that they only look at surviving firms. Gschwandter (2005) examine the period 1950-1999 and examines 85 surviving firms and 75 exiters. He finds that exiters perform more competitively than surviving firms although there is still evidence of profit persistence for both samples. They find that concentration and growth of the industry as well as size and volatility of profits play an important role in explaining persistence. Gschwandtner (2005) looks at the empirical properties of the data. He first tests for stationarity. The existence of a unit root in the firm-level profitability series indicates that shocks to profitability persist indefinitely and that competitive pressures never erode differences in profitability. He then analyzes the speed of adjustment parameter. The speed of adjustment parameter, $\lambda$, should take values between -1 and 1 . This speed of adjustment, lambda, shows how quickly a firms profit rate converges to its long-run level. The smaller the value of lambda, the faster short-run rents are eroded and the stronger the competitive process. If lambda is large then the degree of persistence of past profits is small and therefore short-run rents are not eroded quickly. If lambda is high then competition is not strong enough to bid away short-run rents within one year. The sample of firms examined is said to be less competitive. A negative value of lambda could be due to a high volatility of profits. If a firm 
is oscillating between negative and positive profits a negative lambda is possible. Firms with initially very high or very low profits should have low lambda's because their returns should be converging to the norm. Firms earning normal returns should have relatively high lambdas meaning that there normal returns should tend to persist. Lambda is also a measure of the competitiveness of the sample of firms examined. If lambda is high then the short-run rents are persistent and competition is weak. If lambda is small then short-run rents are quickly eroded and competition is strong.

Gschwandter (2005) then looks at profit persistence. He finds that the results for the survivors are in line with the existing literature. Profits converge on average to a competitive norm, but there is a considerable degree of profit persistence, even after a period of 50 years, the adjustment process is far from complete. What are some explanation for profit persistence? One would expect the concentration in the industry to be related to profit persistence. Highly concentrated industries might be able to construct entry barriers and therefore might be able to elicit a high degree of profit persistence. A number of studies have found a positive relationship between concentration and different measures of profitability (e.g. Kambhampati, 1995; Yurtoglu 2004).

A second industry characteristic that would expected to be related to profit persistence is the size of the industry, measured by the number of firms in the industry. One would expect that the higher the number of firms in the industry, the stronger the competition and therefore less profit persistence. The growth rate of the industry is also an important factor in explaining profit differentials but its net effect is ambiguous. In industries with rapid growth it might be more difficult for incumbents to maintain their market share and oligopolistic discipline thereby profits might decrease. On the other hand, if output is growing fast, firms are not under pressure to 
reduce prices in order to increase sales and therefore profit differentials might be maintained over time. Kambhampati (1995) found a positive and small, but highly significant, coefficient when looking at industry growth and profit persistence. Market share is an important determinant of profitability. The higher the market share (and size of firms), the higher the profitability. The standard deviation of rates of return have been found to be related to profitability.

Geschwandtner and Hauser (2007) analyze the dynamics of profits for 156 US manufacturing companies which managed to survive from 1950 to 1999 . Fractional integration is the methodology used. They argue that this is a plausible estimating procedure over the conventional autoregressive process used in previous work.

\section{Methodology}

The methodology of the paper follows the approach of Mueller (1986) and other persistence of profit studies. Let $\Gamma_{i t}$ denote firm $i$ 's profit rate defined as profits (net income) divided by its total assets in year $t$. To remove the variations in $\Gamma_{i t}$ due to business cycle factors, this measure of profit rate is transformed as the relative deviation from an economy-wide measure of profitability in year $t, \Gamma_{t}$ :

$$
\pi_{i t}=\frac{\Gamma_{i t}-\Gamma_{t}}{\Gamma_{t}}
$$

A firm's profitability in year $t, \pi_{i t}$, is assumed to consist of three components: (1) a competitive return $c$ common to all companies; (2) a permanent rent $r_{i}$ specific to firm $I$; and (3) a short-run rent $s_{i t}$ which is also firm specific and tends to erode over time:

$$
\pi_{i t}=c+r_{i}+s_{i t}
$$


In a perfectly competitive world no firm would be able to earn a rate of return on capital above the competitive return $(c)$, implying that $r_{i}=0$ and $E\left(s_{i t}\right)=0$, as $t \rightarrow \infty$. It is further assumed that short-run rents are correlated over time so that short-run deviations from long-run rates of return may need some periods to reach their competitive level. A reasonable assumption concerning the adjustment process of $s_{i t}$ is that they are intertemporally related but converge on zero,

$$
s_{i t}=\lambda_{i} s_{i t-1}+\mu_{i t}
$$

Where $\left|\lambda_{i}\right|<1$, for stationarity ${ }^{3}$ and $\mu_{i t}$ is an error term with constant variance and mean zero. Assuming that Equation 3 holds in every period, it can be used to remove $s_{i t}$ from Equation 2 to obtain

$$
\pi_{i t}=\left(1-\lambda_{i}\right)\left(c+r_{i}\right)+\lambda_{i} \pi_{i t-1}+\mu_{i t}
$$

Letting $\hat{\alpha}_{i}$ and $\hat{\lambda}_{i}$ be the estimates of the autoregressive equation

$$
\pi_{i t}=\alpha_{i}+\lambda_{i} \pi_{i t-1}+\mu_{i t}
$$

where the unconditional mean of the $\pi_{i t}$ series can be interpreted as the long-run projected profit rate of firm $I, \hat{\pi}_{i p}$,

$$
\hat{\pi}_{i p}=\frac{\hat{\alpha}_{i}}{1-\hat{\lambda}_{i}}
$$

Equation 5 is a simple autoregressive model to describe the pattern of firm level profits over time. The long-run projected profit rate, $\hat{\pi}_{i p}$, and the parameter $\hat{\lambda}_{i}$ can be estimated for individual firms using annual observations of the relative deviation of the profit rate of a given

\footnotetext{
${ }^{3}$ Whereas stationarity requires that $\left|\lambda_{i}\right|<1$, plausible values of $\lambda_{i}$ fall in the range $0 \leq \lambda_{i}<1$.
} 
firm from the annual economy-wide average rate of return. Since $\hat{\pi}_{i p}$ is not defined for unit root processes were $\lambda_{i}=1$ the present methodology is appropriate only for stationary AR processes. For this reason only stationary time series have been considered in the present study.

The two measures of profit persistence used in the literature are $\hat{\pi}_{i p}$ and $\hat{\lambda}_{i}$ where $\hat{\pi}_{i p}$ is a measure of permanent rents, which are not eroded by competitive forces also called the longrun projected profit rate. If all firms earn the competitive rate of return and ignore differences in risk, then $\hat{\pi}_{i p}$ should be equal for all firms.

The second measure for profit persistence $\hat{\lambda}_{i}$ is a measure of the speed of adjustment of short-run profits. The short-run rents can converge slowly (high $\hat{\lambda}_{i}$ ) or fat (low $\left.\hat{\lambda}_{i}\right)$. Companies with initially very high or low profits should have low $\hat{\lambda}_{i}$ 's since their returns should be converging on the norm. Companies earning normal returns should have relatively high $\hat{\lambda}_{i}$ 's, meaning that their normal returns should tend to persist. Lambda is also a measure for the competitiveness of the economy (or the sample0. If lambda is high then short-run rents are persistent and competition is weak. If lambda is small then short-run rents are quickly eroded and competition is strong.

Both parameters are informative and incorporate two views about the competitive process (Geroski, 1990, p. 28). Profits observed at any time reflect the degree of competition in a market and in this neoclassical sense competition can be defined as a state which requires that $\hat{\pi}_{i p}=c$ for all firms (ignoring risk). On the other hand, since high profits attract entry, current profits also cause changes in the degree of competition, thus affect its intensity in the near future. This second Schumpeterian notion views competition as a process in which the forces of entry are 
strong and rapid enough to bid away profits, i.e., as a process, which requires that $\hat{\lambda}_{i}=0$ or sufficiently close to zero.

The expression $\left(1-\lambda_{i}\right)$ is an estimate of the speed of erosion of short-run rents and indicates how quickly the profit rate $\pi_{i t}$ approaches its long-run equilibrium level, $\pi_{i p}$. The bigger $\hat{\lambda}_{i}$ is, the slower short-run rents erode as the profit rate adjusts toward its permanent level. In other words, the observed profit rate in period $t$ depends largely on its value in period $t$ -1 and very little on its permanent level. If $\hat{\lambda}_{i}$ is small, short-run rents erode very rapidly. $\hat{\pi}_{i p}$, on the other hand is a measure of permanent rents, which are not eroded by competitive forces. If all firms earn the competitive rate of return, then $\hat{\pi}_{i p}=c$ for all $i$ and $r_{i}=0$ for all $i$. If $\hat{\pi}_{i p}$ are not equal across firms, then firms earn permanent rents, which indicates that some firms earn returns above (or below) the competitive norm and that these returns are expected to persist indefinitely.

Some studies employ autoregressive parameters greater than unity. In this case the longrun projected profit rate becomes:

$$
\hat{p}_{i}=\frac{\hat{\alpha}_{i}}{1-\left(\sum_{j=1}^{L} \hat{\lambda}_{i j}\right)}
$$

Where $L$ is the number of lags of the AR process and $\hat{\lambda}_{i}=\sum_{j=1}^{L} \hat{\lambda}_{i j}$ is the speed of adjustment parameter. Glen et al. (2001) find for example that $\mathrm{AR}(2)$ is a better method to model profitability. Cable et al. (2001) find in a sample of time series for 53 UK manufacturing firms systematic evidence of cycles (which are usually modelled as AR(2) processes). Our study employs an AR(1) process as test for higher order AR terms indicated that these higher AR terms 
were insignificant. The tests for stationarity and convergence employed in the present study are going to be discussed in a later section.

One drawback in using firm-level data is that a long time-series, which is often desired to improve the reliability of statistical tests, is not available. Therefore, in addition to considering the AR regression in equation (5) for each individual firm, we also considered pooled estimation. Hence, we estimate:

$$
\pi_{i t}=\alpha_{i}+\lambda_{i} \pi_{i t-1}+\mu_{i t}, \quad i=1, \ldots, N \quad t=1, \ldots, T .
$$

One issue key issue in pooled estimation is to whether to consider fixed effects or random effects. Fixed effects estimates a different intercept for each member of the pool, while random effects treats the intercepts as random variables across members of the pool. The fixed effects estimator essentially allows a different constant to be estimated for each member of the pool, while the random effects model assumes a common constant but with a cross-section specific random error term. In estimating the random effects model this error term must be uncorrelated with the regression error term as well as other regressor variables. In order to choose between the two approaches we can conduct the Hausman specification test. This test compares the fixed versus random effects under the null hypothesis that the individual effects are uncorrelated with the other regressors in the model (Hausman 1978). If correlated (the null hypothesis is rejected), a random effect model produces biased estimators, so a fixed effect model is preferred.

The model estimated in equation (5) for individual firms and equation (8) for the pool of firms assumes that the process of reversion back to normal profit is symmetric regardless of whether the starting position is above or below normal profit. That is, estimating a single persistence parameter, $\lambda$, assumes that the persistence of profits is the same for a firm who experiences above normal profit and may be vulnerable to entry as for a firm who experiences 
below normal profit and may be vulnerable to exit. In other words the competitive pressures of entry and exit impact firms identically. We offer some discussion/theory on entry/exit factors and why they maybe asymmetric. In order to consider asymmetry between positive and negative profit deviations from the norm we extend equation (5) and estimate:

$$
\pi_{i t}=\alpha_{i}+\lambda_{1, i} \pi_{i t-1} I_{t-1}+\lambda_{2, i} \pi_{i t-1}\left(1-I_{t-1}\right)+\mu_{i t}
$$

where $I_{t-1}$ is an indicator variable that equals 1 if profit is above normal $\left(\pi_{i t}>0\right)$ an and zero if profit is below or equal to normal $\left(\pi_{i t} \leq 0\right)$. Thus, we are interested in whether $\lambda_{1, i}=\lambda_{2, i}$. Should a test of this hypothesis be rejected then it supports asymmetry in the adjustment path according to whether profits are above or below normal, that is whether entry or exit effects dominate.

\section{Estimation Results}

Annual data is collected on 57 UK non-financial firms over the time period from 1980-2007. The measure of profits is return on assets (return on equity was also consider with similar results) defined as net income over total assets. The individual profit measures were standardised to account of economy-wide variations as discussed in equation (1). Some simple descriptive statistics are reported in Table 1, while Figure 1 presents the distribution (density) of the profits rates, which is smoothed using the Epanechnikov kernel function. The evidence in this table and graph shows that while the mean value is close to zero, there is substantial variation and a highly non-normal distribution, with evidence of negative skewness and leptokurtosis.

The estimates of the persistence parameter $\lambda$ are presented in Table 2 for each individual firm, while Figure 2 and Table 3 present the same information in a more accessible fashion. In particular, Figure 2 presents the density function, while Table 3 groups the estimated persistence parameter. The evidence from this set of information suggests that profit persistence in the data 
is typically positive, although some negative values are reported. Furthermore, the value of the parameter is in the range $0-0.5$ for the majority of the series considered (approximately $60 \%$ ). However, notwithstanding this, a quarter of the series do exhibit a high degree of persistence and hence low reversion of profits back to normal (equilibrium). Nonetheless, the highest persistence parameter is estimated at 0.78 , which is not suggestive of non-stationary behaviour. In order to provide some further interpretation to the raw persistence figures, Table 2 also presents half-life decay estimates, these are calculated as $\log (0.5) / \log (\lambda)$ and measures in time the length it takes for half of a shock to profits to decay back to normal. For example, for firm X2 the half-life decay is 0.51 years (or approximately 6 months), while for firm X3 half-life decay is 2.79 years (or approximately 33 months). The density function in Figure 2 likewise suggests that the majority of the estimated persistence parameters are clustered around a moderate positive value, indicating some persistence and with a range of values around that mean, but with no evidence of values greater than one.

The pooled estimation results for equation (5) are reported in the first row of Table 4 for the fixed effects and random effects model. In both model specifications the autoregressive parameter is positive and significant suggesting some persistence in profits. However, the two specifications disagree as the extent of the persistence, in particular, the random effects model suggests a high degree of persistence, whereas the fixed effects model suggest a more moderate measure (although still suggesting a reasonable degree of profit persistence). In order to discriminate between these two specifications we conduct the Hausman test, the null of which is that the individual effects are uncorrelated with the other model regressors. Should the null be rejected then the fixed effect model is preferred, while the estimates of the random effects model will be biased. The results of the Hausman test are reported in row five of Table 4 and indeed 
suggest rejection of the null hypothesis, bias in the random effects coefficient estimates and preference for the fixed effects model.

Table 5 presents the results of the TAR model in equation (9). Here a different picture from the linear AR(1) model is presented. The range of values that the estimated parameters now take varies widely and indicates evidence of local non-stationary behaviour. This can be seen more clearly in Figure 3 and Table 6 where the same information as for the linear AR model is presented, in terms of the distribution of the persistence parameter across the regimes. For example, in Figure, which presents the density graphs, there are several examples of persistence values being greater than one (in absolute terms), particularly so for the above average profits regime. In terms of comparing the two parameter values for each firm, the value of $\lambda$ associated with above normal profits is typically higher than the value of $\lambda$ associated with below normal profits. For all firms with above normal profits the average value of $\lambda$ is 0.60 . For all firms with below normal profits the average value of $\lambda$ is 0.20 . Moreover, out of the 54 firms for which the TAR model is estimated for firms with above normal profits the value of $\lambda$ is largest for 33 firms $(61 \%)$. This evidence points to the view that persistence is higher for above average profit firms, suggesting that the factors determining entry are less effective in restoring the competitive equilibrium than the factors determining exit. In order to determined whether there is any statistical difference in the estimated coefficients, for each regression we conduct a Wald test of the null hypothesis $\lambda_{1, i}=\lambda_{2, i}$. The results of the Wald test are also reported in Table 5 . These statistics indicate that for only twelve series do we find a statistically significant difference (at the $10 \%$ significance level), however, one must consider the small number of data points.

We now turn our attention to the pooled estimation. The pooled estimation results are reported in the second and third row of Table 4, while the accompanying Wald coefficient 
equality test is reported in row four and the appropriate Hausman test is reported in the sixth row. The results for both the fixed effects and random effects model suggest that persistence is higher for above average profits than for below average profits. Moreover, on the basis of the Wald tests these differences are statistically significant, while again the Hausman tests supports the fixed effects model and suggest possible bias within the random effects model. Thus, the results of the TAR model suggest that above normal profits persist significantly longer than below normal profits, in other words the competitive forces governing entry are less effective in restoring the competitive equilibrium than the forces governing exit.

The above results suggest that firms with above normal profits have high barriers to entry and exit. Those firms with profits below normal have low barriers to enter and exit. One argument for the above finding is that those firms where entry and exist is easy (profits above normal) have become efficient and have developed economies of scale, both forcing out inefficient firms. These firms will find that they have little incentive to leave the industry and have erected barriers to entry, with firms having little incentive to exist. In contrast, those firms that have profits below normal, find exist and entry easy. These firms may be inefficient and have small barriers to entry and exit. These lead to below normal profits as competitive pressures operate.

\section{Conclusions and Policy Implications}

A large body of research has been written over the years on profit persistence yet questions still prevail in the empirical literature. With some exceptions, the methodology employed in this literature to measure persistence of profits is base on a first-order autoregressive model. This paper seeks to extend the existing literature in two ways. First, we 
update the results to include a more recent time period than the existing research. Our data set employs 57 firms and conducts estimation over the period 1980-2007, whereas most of the existing literature uses data that stops before 2000. This may be of importance given the significant stock market turbulence over the period, as well as the preceding bubble, which has led to substantial turnover of firms, entering and exiting. The second, and perhaps more significant, aim of the paper is to consider an asymmetric autoregressive model. This paper allows the parameter governing persistence to vary between positive and negative profits relative to normal profits. Thus, we are able to differentiate between entry and exit as conduits of the competitive model. Moreover, should the persistence parameters be asymmetric, then this sheds light on whether the threat of entry or exit is more dominant in asserting the competitive equilibrium. Such information may be of importance to policy makers in establishing competition legislation.

We find that there is a great degree of profit persistence in our sample. We find this to be true using univariate analysis as well as pooled fixed affect analysis. We find firms with profits above normal are firms that have high barriers to entry and exit while firms with below normal profits have low barriers to entry and exit. 


\section{REFERENCES}

Cable, J. and Jackson, R.H.G., "The Persistence of Profits in the Long-run: A New Approach," mimeo, School of Management and Business, University of Wales, Aberystwyth, UK (2003)

Cable, J. and Jackson, R.H.G., Rhys, H., "Profit Cycles: The Dynamics of Corporate Earnings Revisited," mimeo, School of Management and Business, University of Wales, Aberystwyth, UK (2001)

Crespo-Cuareshma J. and Geschwandtner, A., "Tracing the Dynamics of Competition: Evidence From Company Profits," Working paper 0504, Department of Economics, University of Vienna, (2005)

Crespo-Cuareshma and Geschwandtner, "The Competitive Environment Hypothesis Revisited: Nonlinearity, Nonstationatity and Profit Persistence,", Applied Economics, 38 (2006): 465-467.

Cubbin, J., Geroski, P.A., "The Convergence of Profits in the Long-run: Inter-firm and InterIndustry Comparisons, Journal of Industrial Economics, 35 (1987): 427-442.

Cubbin, J., Geroski, P.A., "The Persistence of Profits in the United Kingdom," Mueller, D.C. (ed.) in The Dynamics of Company Profits: An International Comparison, Cambridge University Press, Cambridge (1990): 147-167.

Droucopoulos, V., and Lianos, T., "The persistence of profits in the Greek manufacturing industry," International Review of Applied Economics, 7 (1993): 163-176.

Geroski, P.A., and Jacquemin A., "The Persistence of Profits: A European Comparison," The Economic Journal, 98 (1988): 375-389.

Geroski, P.A.., "Modelling Persistent Profitability. In: Mueller., D.C. (Ed.), The Dynamics of Company Profits: An international Comparison. Cambridge University Press, Cambridge (1990).

Glen, J., Lee, K., and Singh, A., "Persistence of Profitability and Competition in Emerging Markets," Economics Letters, 72 (2001): 247-253.

Goddard, J.A., and Wilson, J.O.S., "Persistence of Profits for UK manufacturing and service sector firms," Service Industries Journal, 16 (1996): 105-117.

Goddard, J.A., and Wilson, J.O.S., "The Persistence of Profits: A New Empirical Interpretation," International Journal of Industrial Organization, 17 (1999): 663-687.

Gschwandtner, Adelina, "Profit Persistence in the 'Very' Long-run: Evidence From Survivors 
and Exiters", Applied Economics. 37 (2005): 793-806

Gschwandtner, Adelina and Hauser, Michael A., "Modeling Profit Series: Nonstationarity and Long Memory." Applied Economics, (2007): 1-8.

Haussman, James A., "Specification Tests in Econometrics, Econometrica, 46 (1978): 12511271.

Ioannidis, C., Peel, D. A. , Venetis, I.A., "On the Persistent of Profit: Some New Results," (2003) Mimeo, Cardiff Business School, Cardiff University, Wales, UK

Kambhampati, U.S., “The Persistence of Profit Differentials in Indian Industry," Applied Economics, 27 (1995): 353-361

Khemani, R.S., Shapiro, D.M., "The Persistence of Predictability in Canada," Mueller, D.C. (ed.) in The Dynamics of Company Profits: An International Comparison, Cambridge University Press, Cambridge (1990): 77-104.

Maruyama, M. and Odagiri, H., "Does the 'Persistence of Profits' Persist? A Study of Company Profits in Japan, 1964-1997," International Journal of Industrial Organization, 20 (2002): 1513-1533.

McGahan, A.M., and Porter, M.E., "The Persistence of Shocks to Profitability," The Review of Economics and Statistics, 81(1) (1999): 143-53.

Mueller, D.C., “The Persistence of Profits Above the Norm,” Economica, 44 (1977): 369-380.

Mueller, D.C., Profits in the Long-run, Cambridge University Press, (1986)

Mueller, D.C., (Ed.) The Dynamics of Company Profits: An International Comparison, Cambridge University Press, Cambridge (1990a)

Mueller, D.C., "The Persistence of Profits in the United States," in (Ed.) The Dynamics of Company Profits: An International Comparison, Cambridge University Press, Cambridge (1990b) “35-57.

Odagiri, H., and Hayawaki, H, “The Persistence of Profits in Japan," Mueller, D.C. (ed.) in The Dynamics of Company Profits: An International Comparison, Cambridge University Press, Cambridge (1990): 169-185.

Odagiri, H., Yamawaki, H., "A Study of Company Profit-rate Time Series: Japan and the United States," International Journal of Industrial Organization, 4 (1986): 1-23.

Odagiri, H., Yamawaki, H., "The Persistence of Profits in Japan," in Mueller, D.C. (ed.) in The Dynamics of Company Profits: An International Comparison, Cambridge University 
Press, Cambridge (1990a): 129-146.

Odagiri, H., Yamawaki, H., "The Persistence of Profits: International Comparison," in Mueller, D.C. (ed.) in The Dynamics of Company Profits: An International Comparison, Cambridge University Press, Cambridge (1990b): 169-185.

Schohl, F., "Persistence of Profits in the Long-run: A Critical Extension of Some Recent Findings," International Journal of Industrial Organization, 8 (1990): 385-404.

Schwalbach, J., and Mahmood, T. "The Persistence of Corporate Profits in the Federal Republic of Germany," in D.C. Mueller, (ed.) The Dynamics of Company Profits: An International Comparison, Cambridge University Press, Cambridge (1990) pp. 105-121.

Schwalbach, J., Grasshof, U., and Mahmood. T., "The Dynamics of Corporate Profits," European Economic Review, 33, (1989): 1625-1639.

Waring, G., "Industry Differences in the Persistence of Firm-Specific Returns," American Economic Review, 86 (1996): 1253-1265.

Yurtoglu, B.B., "Ownership, control and performance of Turkish listed companies,” Empirica, 2 (2000): 193-222.

Yurtoglu, B.B., "Persistence of Firm-Level Profitability in Turkey," Applied Economics, 36 (6) (2004): 615-625. 


\begin{tabular}{|l|l|}
\hline \multicolumn{2}{|c|}{ Table 1. Distribution of Pooled Profits } \\
\hline Mean & 0.0133 \\
\hline Median & 0.0221 \\
\hline Maximum & 6.5879 \\
\hline Minimum & -29.5236 \\
\hline Skewness & -8.8946 \\
\hline Kurtosis & 193.3858 \\
\hline JB & $2.43 \mathrm{e}+05$ \\
& $(0.00)$ \\
\hline $\begin{array}{l}\text { Notes: JB refers to the Jarque-Bera test } \\
\text { parenthesis below. }\end{array}$ \\
\hline
\end{tabular}


Table 2. AR(1) Persistence Measures.

\begin{tabular}{|l|l|l|l|l|l|l|l|l|}
\hline & & & & & & & & \\
\hline Co & AR(1) & $\begin{array}{l}\text { Half- } \\
\text { Life }\end{array}$ & Co & AR(1) & $\begin{array}{l}\text { Half- } \\
\text { Life }\end{array}$ & Co & AR(1) & Half-Life \\
\hline X1 & 0.20 & 0.43 & $\mathrm{X} 21$ & 0.72 & 2.11 & $\mathrm{X} 44$ & 0.20 & 0.43 \\
\hline X2 & 0.26 & 0.51 & $\mathrm{X} 23$ & 0.46 & 0.89 & $\mathrm{X} 45$ & -0.003 & $\mathrm{Na}$ \\
\hline $\mathrm{X} 3$ & 0.78 & 2.79 & $\mathrm{X} 24$ & 0.36 & 0.68 & $\mathrm{X} 46$ & 0.24 & 0.49 \\
\hline $\mathrm{X} 4$ & 0.39 & 0.74 & $\mathrm{X} 25$ & 0.39 & 0.74 & $\mathrm{X} 47$ & -0.72 & $\mathrm{Na}$ \\
\hline $\mathrm{X} 5$ & -0.01 & $\mathrm{Na}$ & $\mathrm{X} 26$ & 0.19 & 0.42 & $\mathrm{X} 48$ & 0.25 & 0.50 \\
\hline $\mathrm{X} 6$ & 0.17 & 0.39 & $\mathrm{X} 27$ & -0.001 & $\mathrm{Na}$ & $\mathrm{X} 49$ & 0.005 & 0.13 \\
\hline $\mathrm{X} 7$ & 0.77 & 2.65 & $\mathrm{X} 28$ & 0.71 & 2.02 & $\mathrm{X} 50$ & 0.77 & 2.65 \\
\hline $\mathrm{X} 8$ & 0.64 & 1.55 & $\mathrm{X} 29$ & 0.14 & 0.35 & $\mathrm{X} 51$ & 0.60 & 1.36 \\
\hline $\mathrm{X} 9$ & 0.42 & 0.80 & $\mathrm{X} 30$ & 0.06 & 0.25 & $\mathrm{X} 52$ & 0.07 & 0.26 \\
\hline $\mathrm{X} 10$ & 0.31 & 0.59 & $\mathrm{X} 31$ & 0.02 & 0.18 & $\mathrm{X} 53$ & 0.42 & 0.80 \\
\hline $\mathrm{X} 11$ & -0.10 & $\mathrm{Na}$ & $\mathrm{X} 32$ & 0.35 & 0.66 & $\mathrm{X} 54$ & 0.17 & 0.39 \\
\hline $\mathrm{X} 12$ & 0.54 & 1.12 & $\mathrm{X} 33$ & 0.40 & 0.76 & $\mathrm{X} 55$ & 0.37 & 0.70 \\
\hline $\mathrm{X} 13$ & 0.08 & 0.27 & $\mathrm{X} 35$ & 0.31 & 0.59 & $\mathrm{X} 56$ & -0.07 & Na \\
\hline $\mathrm{X} 14$ & 0.21 & 0.44 & $\mathrm{X} 36$ & 0.73 & 2.20 & $\mathrm{X} 57$ & 0.56 & 1.20 \\
\hline $\mathrm{X} 15$ & 0.30 & 0.58 & $\mathrm{X} 37$ & 0.65 & 1.61 & & & \\
\hline $\mathrm{X} 16$ & 0.42 & 0.80 & $\mathrm{X} 38$ & 0.45 & 0.87 & & & \\
\hline $\mathrm{X} 17$ & 0.25 & 0.50 & $\mathrm{X} 40$ & 0.13 & 0.34 & & & \\
\hline $\mathrm{X} 18$ & 0.17 & 0.39 & $\mathrm{X} 41$ & 0.74 & 2.30 & & & \\
\hline $\mathrm{X} 19$ & 0.14 & 0.35 & $\mathrm{X} 42$ & 0.44 & 0.84 & & & \\
\hline $\mathrm{X} 20$ & 0.25 & 0.50 & $\mathrm{X} 43$ & 0.24 & 0.49 & & & \\
\hline
\end{tabular}




\begin{tabular}{|l|l|l|l|l|}
\hline \multicolumn{5}{|c|}{ Table 3. Distribution of Persistence Measure } \\
\hline Value & Count & Percentage & Cum. Count & Cum. Percentage \\
\hline$[-1,-0.5]$ & 1 & 1.75 & 1 & 1.75 \\
\hline$[-0.5,0]$ & 5 & 8.77 & 6 & 10.53 \\
\hline$[0,0.5]$ & 36 & 63.16 & 42 & 73.68 \\
\hline$[0.5,1]$ & 15 & 26.32 & 57 & 100 \\
\hline Total & 57 & 100 & 57 & 100 \\
\hline & & & & \\
\hline & & & & \\
\hline & & & & \\
\hline
\end{tabular}




\begin{tabular}{|l|l|l|}
\hline \multicolumn{3}{|c|}{ Table 4. Pooled Estimation Persistence Coefficient Estimates } \\
\hline & FE & RE \\
\hline Linear $-\lambda$ & 0.39 & 0.82 \\
& $(15.94)$ & $(51.03)$ \\
\hline TAR $-\lambda$ Positive & 0.59 & 1.05 \\
& $(15.19)$ & $(38.61)$ \\
\hline TAR $-\lambda$ Negative & 0.20 & 0.61 \\
& $(5.30)$ & $(25.44)$ \\
\hline Wald - TAR $\lambda$ Equality & 41.17 & 113.97 \\
& $(0.00)$ & $(0.00)$ \\
\hline Hausman & Linear & 80.36 \\
& & $(0.00)$ \\
\hline & TAR & 83.27 \\
& & $(0.00)$ \\
\hline & & \\
\hline & & \\
\hline
\end{tabular}


Table 5. TAR(1) Persistence Measures

\begin{tabular}{|c|c|c|c|c|c|c|c|c|c|c|c|}
\hline & & & & & & & & & & & \\
\hline Co & $\begin{array}{l}\text { AR(1) } \\
\text { Pos }\end{array}$ & $\begin{array}{l}\text { AR(1) } \\
\text { Neg }\end{array}$ & Wald & $\mathrm{Co}$ & $\begin{array}{l}\text { AR(1) } \\
\text { Pos }\end{array}$ & $\begin{array}{l}\text { AR(1) } \\
\text { Neg }\end{array}$ & $\begin{array}{l}\text { Wal } \\
\text { d }\end{array}$ & Co & $\begin{array}{l}\operatorname{AR}(1) \\
\text { Pos }\end{array}$ & $\begin{array}{l}\text { AR(1) } \\
\text { Neg }\end{array}$ & Wald \\
\hline $\mathrm{X} 1$ & $\begin{array}{l}0.51 \\
(0.62) \\
\end{array}$ & $\begin{array}{l}0.11 \\
(0.35) \\
\end{array}$ & 0.69 & $\mathrm{X} 21$ & $\begin{array}{l}0.69 \\
(3.27) \\
\end{array}$ & $\begin{array}{l}0.77 \\
(2.13) \\
\end{array}$ & 0.88 & X44 & $\begin{array}{l}0.60 \\
(0.50) \\
\end{array}$ & $\begin{array}{l}0.16 \\
(0.67) \\
\end{array}$ & 0.73 \\
\hline $\mathrm{X} 2$ & $\begin{array}{l}0.63 \\
(0.68) \\
\end{array}$ & $\begin{array}{l}0.21 \\
(0.93) \\
\end{array}$ & 0.68 & $\mathrm{X} 23$ & $\begin{array}{l}0.62 \\
(1.77) \\
\end{array}$ & $\begin{array}{l}0.31 \\
(0.93)\end{array}$ & 0.59 & $\mathrm{X} 45$ & $\begin{array}{l}0.18 \\
(0.60) \\
\end{array}$ & $\begin{array}{l}-0.23 \\
(-0.67) \\
\end{array}$ & 0.41 \\
\hline $\mathrm{X} 3$ & $\begin{array}{l}0.96 \\
(3.56) \\
\end{array}$ & $\begin{array}{l}0.59 \\
(2.15) \\
\end{array}$ & 0.45 & $\mathrm{X} 24$ & $\begin{array}{l}1.20 \\
(2.04) \\
\end{array}$ & $\begin{array}{l}0.17 \\
(0.75) \\
\end{array}$ & 0.13 & X46 & $\begin{array}{l}0.36 \\
(1.40) \\
\end{array}$ & $\begin{array}{l}-0.12 \\
(-0.24) \\
\end{array}$ & 0.45 \\
\hline $\mathrm{X} 4$ & $\begin{array}{l}0.68 \\
(1.08)\end{array}$ & $\begin{array}{l}0.34 \\
(1.60) \\
\end{array}$ & 0.63 & $\mathrm{X} 25$ & $\begin{array}{l}1.10 \\
(2.82) \\
\end{array}$ & $\begin{array}{l}-0.07 \\
(-0.23) \\
\end{array}$ & 0.03 & X47 & $\begin{array}{l}0.02 \\
(0.04) \\
\end{array}$ & $\begin{array}{l}-1.71 \\
(-2.40) \\
\end{array}$ & 0.10 \\
\hline $\mathrm{X} 5$ & $\begin{array}{l}-0.02 \\
(-0.08) \\
\end{array}$ & $\begin{array}{l}0.06 \\
(0.04) \\
\end{array}$ & 0.96 & X26 & $\begin{array}{l}-0.02 \\
(-0.04) \\
\end{array}$ & $\begin{array}{l}0.25 \\
(0.96) \\
\end{array}$ & 0.71 & X48 & $\begin{array}{l}1.39 \\
(0.76) \\
\end{array}$ & $\begin{array}{l}0.21 \\
(1.02) \\
\end{array}$ & 0.53 \\
\hline $\mathrm{X} 6$ & $\begin{array}{l}1.20 \\
(2.07) \\
\end{array}$ & $\begin{array}{l}-0.04 \\
(-0.18) \\
\end{array}$ & 0.06 & $\mathrm{X} 27$ & $\begin{array}{l}0.93 \\
(0.78) \\
\end{array}$ & $\begin{array}{l}-0.09 \\
(-0.36) \\
\end{array}$ & 0.43 & X49 & $\begin{array}{l}1.27 \\
(2.93) \\
\end{array}$ & $\begin{array}{l}-0.50 \\
(-2.14) \\
\end{array}$ & 0.00 \\
\hline $\mathrm{X} 7$ & $\begin{array}{l}0.21 \\
(0.76)\end{array}$ & $\begin{array}{l}1.42 \\
(4.58) \\
\end{array}$ & 0.02 & $\mathrm{X} 28$ & $\begin{array}{l}0.69 \\
(3.27) \\
\end{array}$ & $\begin{array}{l}0.75 \\
(1.11) \\
\end{array}$ & 0.95 & X50 & $\begin{array}{l}1.18 \\
(3.58) \\
\end{array}$ & $\begin{array}{l}0.48 \\
(1.83)\end{array}$ & 0.18 \\
\hline $\mathrm{X} 8$ & $\begin{array}{l}1.15 \\
(6.11)\end{array}$ & $\begin{array}{l}-0.18 \\
(-0.68)\end{array}$ & 0.00 & X29 & $\begin{array}{l}2.72 \\
(1.60)\end{array}$ & $\begin{array}{l}0.02 \\
(0.09)\end{array}$ & 0.13 & X51 & $\begin{array}{l}0.62 \\
(3.16)\end{array}$ & $\begin{array}{l}0.46 \\
(0.59)\end{array}$ & 0.86 \\
\hline $\mathrm{X} 9$ & $\begin{array}{l}-0.29 \\
(-0.29)\end{array}$ & $\begin{array}{l}0.48 \\
(2.35)\end{array}$ & 0.48 & X30 & $\begin{array}{l}0.68 \\
(1.31)\end{array}$ & $\begin{array}{l}-0.14 \\
(-0.57)\end{array}$ & 0.20 & X52 & $\begin{array}{l}-0.09 \\
(-0.18)\end{array}$ & $\begin{array}{l}0.16 \\
(0.50)\end{array}$ & 0.73 \\
\hline $\mathrm{X} 10$ & $\begin{array}{l}0.31 \\
(1.15) \\
\end{array}$ & $\begin{array}{l}0.31 \\
(0.86) \\
\end{array}$ & 1.00 & X31 & $\begin{array}{l}0.63 \\
(0.86)\end{array}$ & $\begin{array}{l}-0.07 \\
(-0.30) \\
\end{array}$ & 0.39 & X53 & $\begin{array}{l}0.41 \\
(1.76) \\
\end{array}$ & $\begin{array}{l}0.47 \\
(0.79) \\
\end{array}$ & 0.93 \\
\hline $\mathrm{X} 11$ & $\begin{array}{l}-1.98 \\
(-4.06) \\
\end{array}$ & $\begin{array}{l}0.35 \\
(1.82) \\
\end{array}$ & 0.00 & X32 & $\begin{array}{l}0.46 \\
(1.59) \\
\end{array}$ & $\begin{array}{l}0.11 \\
(0.21)\end{array}$ & 0.61 & X54 & $\begin{array}{l}0.08 \\
(0.10) \\
\end{array}$ & $\begin{array}{l}0.19 \\
(0.64)\end{array}$ & 0.90 \\
\hline $\mathrm{X} 12$ & $\begin{array}{l}1.26 \\
(1.10) \\
\end{array}$ & $\begin{array}{l}0.47 \\
(2.31) \\
\end{array}$ & 0.52 & X33 & $\begin{array}{l}0.12 \\
(0.33) \\
\end{array}$ & $\begin{array}{l}0.67 \\
(2.03) \\
\end{array}$ & 0.33 & X55 & $\begin{array}{l}0.61 \\
(2.22) \\
\end{array}$ & $\begin{array}{l}0.10 \\
(0.31) \\
\end{array}$ & 0.27 \\
\hline $\mathrm{X} 13$ & $\begin{array}{l}0.47 \\
(1.60) \\
\end{array}$ & $\begin{array}{l}-0.60 \\
(-1.38) \\
\end{array}$ & 0.08 & X35 & $\begin{array}{l}1.22 \\
(1.72) \\
\end{array}$ & $\begin{array}{l}-0.05 \\
(-0.14) \\
\end{array}$ & 0.16 & X56 & $\begin{array}{l}0.25 \\
(0.65) \\
\end{array}$ & $\begin{array}{l}-0.36 \\
(-1.00) \\
\end{array}$ & 0.33 \\
\hline $\mathrm{X} 14$ & $\begin{array}{l}0.30 \\
(1.00)\end{array}$ & $\begin{array}{l}0.06 \\
(0.13) \\
\end{array}$ & 0.70 & X36 & $\begin{array}{l}0.95 \\
(7.24)\end{array}$ & $\begin{array}{l}-0.98 \\
(-1.86) \\
\end{array}$ & 0.00 & X57 & $\begin{array}{l}0.55 \\
(3.03) \\
\end{array}$ & $\begin{array}{l}1.21 \\
(0.28) \\
\end{array}$ & 0.88 \\
\hline $\mathrm{X} 15$ & $\begin{array}{l}0.07 \\
(0.11) \\
\end{array}$ & $\begin{array}{l}0.34 \\
(1.55) \\
\end{array}$ & 0.72 & X37 & $\begin{array}{l}0.61 \\
(2.34) \\
\end{array}$ & $\begin{array}{l}0.90 \\
(1.03)\end{array}$ & 0.77 & & & & \\
\hline X16 & $\begin{array}{l}0.34 \\
(1.42) \\
\end{array}$ & $\begin{array}{l}0.63 \\
(1.35) \\
\end{array}$ & 0.62 & X38 & $\begin{array}{l}1.88 \\
(0.88)\end{array}$ & $\begin{array}{l}0.39 \\
(1.87) \\
\end{array}$ & 0.50 & & & & \\
\hline $\mathrm{X} 17$ & $\begin{array}{l}-0.01 \\
(-0.01)\end{array}$ & $\begin{array}{l}0.37 \\
(1.36)\end{array}$ & 0.54 & $\mathrm{X} 40$ & $\begin{array}{l}1.09 \\
(1.78)\end{array}$ & $\begin{array}{l}-0.15 \\
(-0.59)\end{array}$ & 0.10 & & & & \\
\hline $\mathrm{X} 18$ & $\begin{array}{l}-0.49 \\
(-0.56)\end{array}$ & $\begin{array}{l}0.28 \\
(1.14) \\
\end{array}$ & 0.44 & $\mathrm{X} 41$ & $\begin{array}{l}0.72 \\
(3.88) \\
\end{array}$ & $\begin{array}{l}0.80 \\
(1.39) \\
\end{array}$ & 0.91 & & & & \\
\hline X19 & $\begin{array}{l}2.79 \\
(2.01) \\
\end{array}$ & $\begin{array}{l}-0.09 \\
(-0.40) \\
\end{array}$ & 0.05 & $\mathrm{X} 42$ & $\begin{array}{l}0.56 \\
(0.47)\end{array}$ & $\begin{array}{l}0.43 \\
(2.15) \\
\end{array}$ & 0.92 & & & & \\
\hline $\mathrm{X} 20$ & $\begin{array}{l}-0.11 \\
(-0.41) \\
\end{array}$ & $\begin{array}{l}0.86 \\
(2.16) \\
\end{array}$ & 0.08 & $\mathrm{X} 43$ & $\begin{array}{l}0.16 \\
(0.58) \\
\end{array}$ & $\begin{array}{l}0.36 \\
(0.96) \\
\end{array}$ & 0.73 & & & & \\
\hline
\end{tabular}




\begin{tabular}{|c|c|c|c|c|}
\hline \multicolumn{5}{|c|}{ Table 6. Distribution of Persistence Measure } \\
\hline Value & Count & Percentage & Cum. Count & Cum. Percentage \\
\hline \multicolumn{5}{|c|}{ Above Normal Profits Regime } \\
\hline$[-2,-1]$ & 1 & 1.85 & 1 & 1.85 \\
\hline$[-1,0]$ & 7 & 12.96 & 8 & 14.81 \\
\hline$[0,1]$ & 33 & 61.11 & 41 & 75.93 \\
\hline$[1,2]$ & 11 & 20.37 & 52 & 96.30 \\
\hline$[2,3]$ & 2 & 3.70 & 54 & 100 \\
\hline Total & 54 & 100 & 54 & 100 \\
\hline \multicolumn{5}{|c|}{ Below Normal Profits Regime } \\
\hline$[-2,-1]$ & 1 & 1.85 & 1 & 1.85 \\
\hline$[-1,0]$ & 15 & 27.78 & 16 & 29.63 \\
\hline$[0,1]$ & 36 & 66.67 & 52 & 96.30 \\
\hline$[1,2]$ & 2 & 3.70 & 54 & 100 \\
\hline Total & 54 & 100 & 54 & 100 \\
\hline & & & & \\
\hline
\end{tabular}



Figure 1. Distribution of Profits

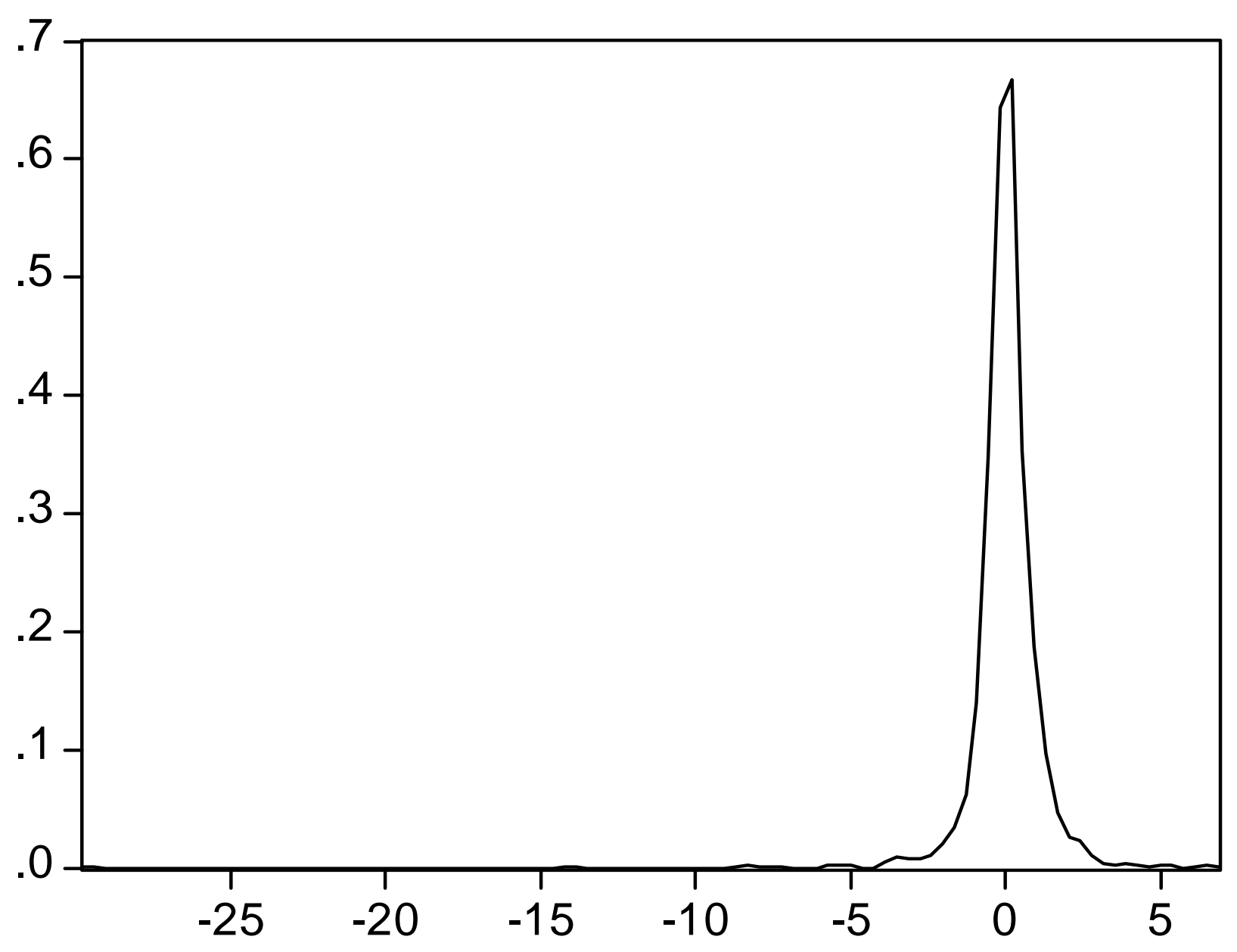


Figure 2. Distribution of Estimated Persistence Parameter

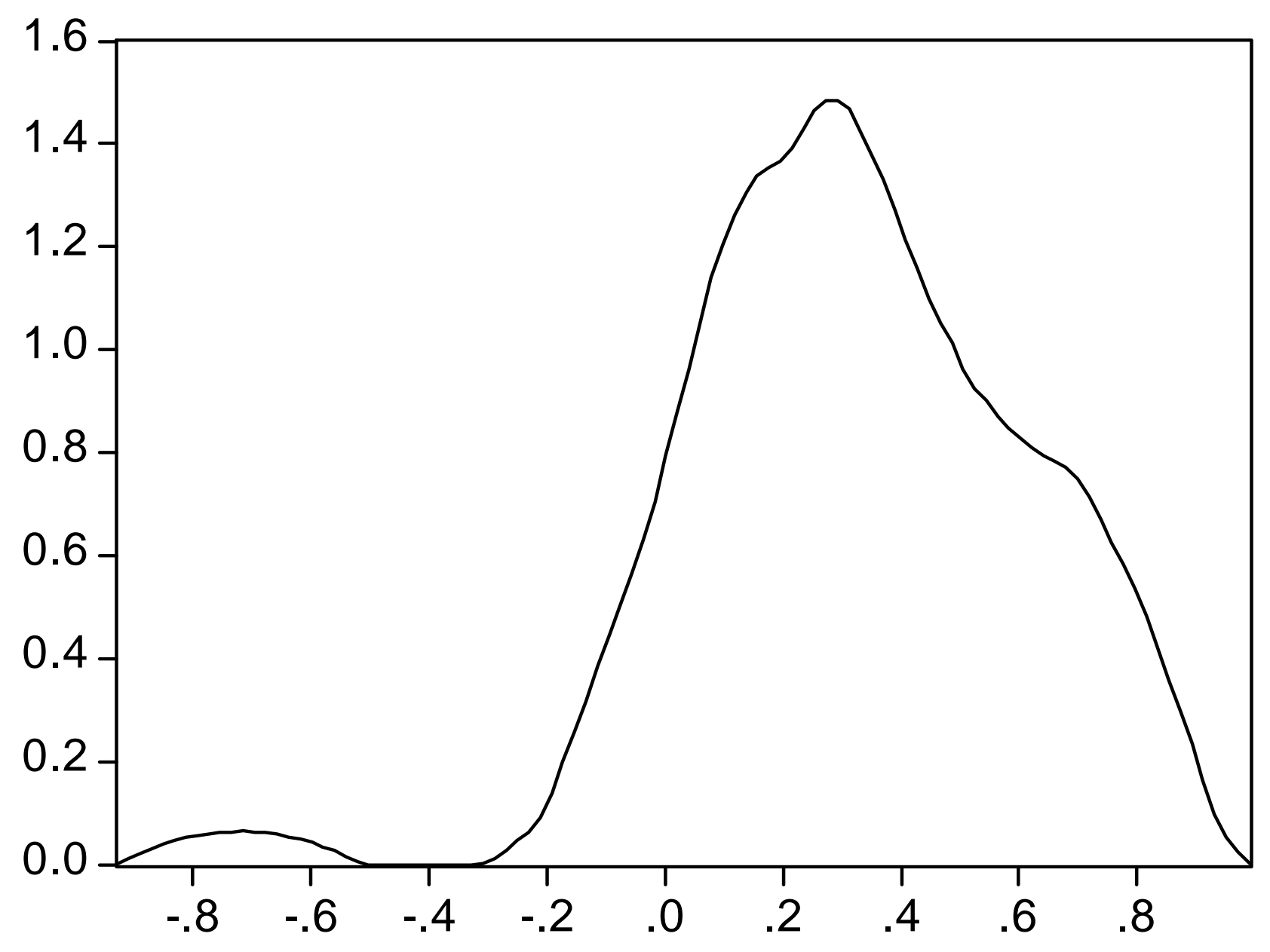


Figure 3. Distribution of Estimated Persistence Parameter TAR Model

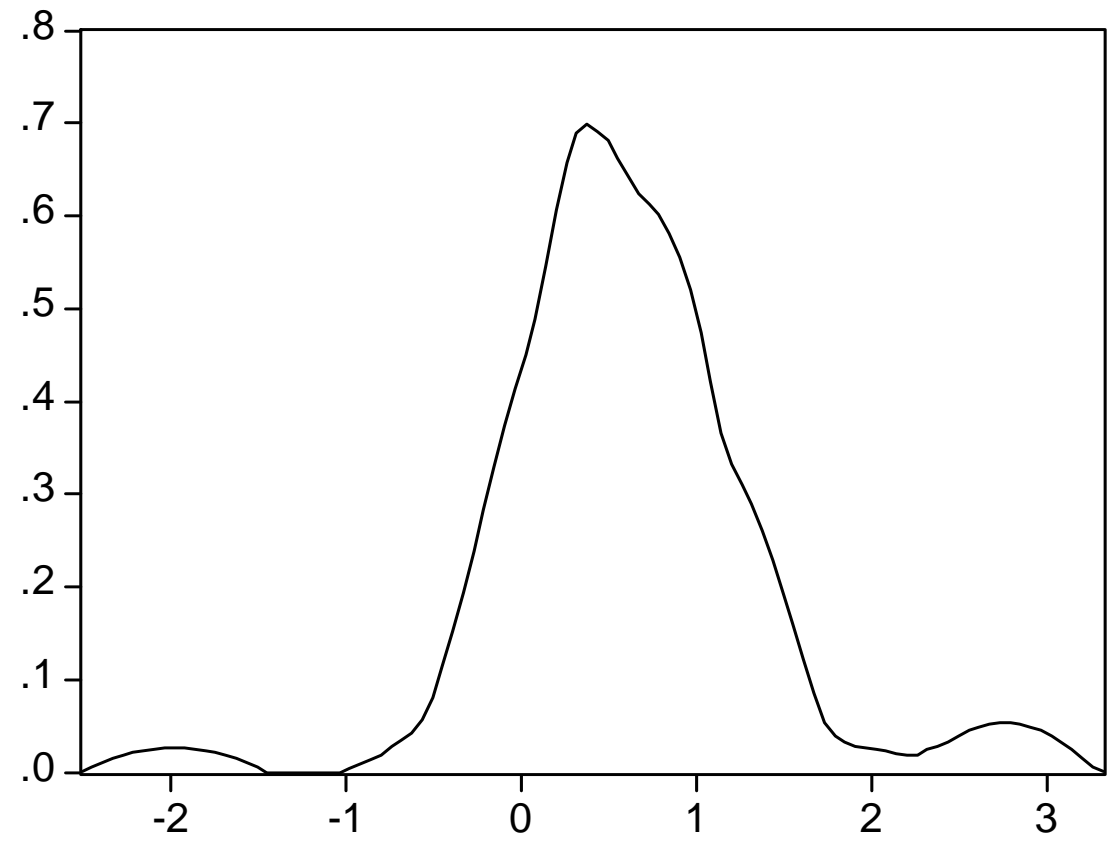

Above Normal Profit Regime

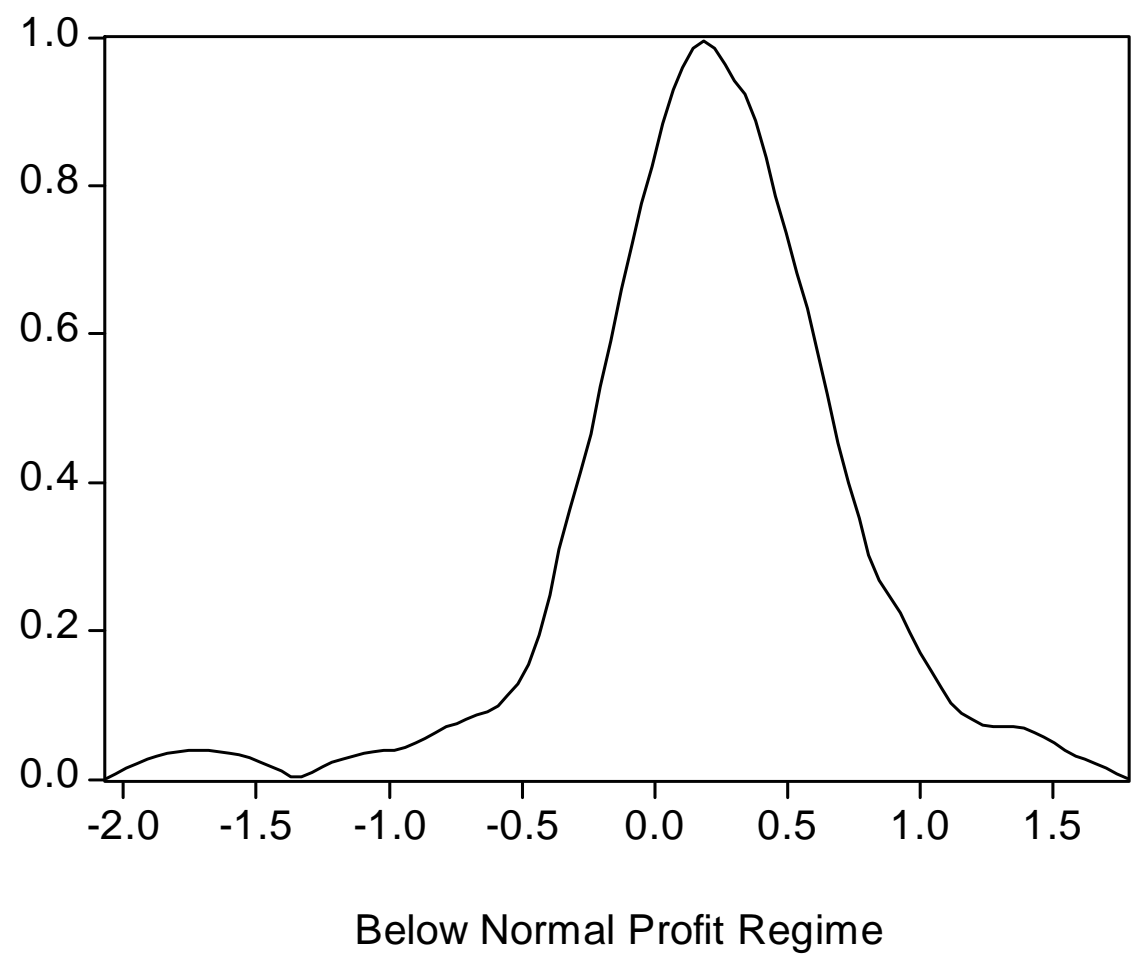

